The Disability Discrimination Act:

Time for the Stick?

\author{
Dr Graham A. Miller \\ University of Westminster \\ 35 Marylebone Road \\ London \\ NW1 5LS \\ Tel: +44 2079115000 ext 3054 \\ Fax: +44 2079115171 \\ Email: G.Miller01@wmin.ac.uk
}

\author{
Emma Kirk
}

South Bank University

Southwark Campus

103 Borough Road

London

SE1 0AA 


\title{
The Disability Discrimination Act: Time for the Stick?
}

\begin{abstract}
This paper explores the extent to which the UK tourism industry has accepted the increased standards of performance under the new Disability Discrimination Act. The research utilises the mystery shopper technique to request basic information from two hundred and ten randomly selected companies from various sectors of the tourism industry. The request stated that the mystery shopper is visually impaired and would like to use the services provided by the company. Results show generally an extremely low ability of organisations to meet the simple requests made, although some sectors of the industry were more able to comply than others.
\end{abstract}

Keywords: Disability, Discrimination, Access

\section{Introduction}

Hunter (1995) describes the dominant paradigm of sustainable tourism as being too "tourismcentric" when what is needed is a less parochial approach to the topic. Whether a narrow definition is taken, which relates more to the sustaining of the tourism industry, or the broader definition, which equates to tourism that promotes sustainable development, issues of equity and fairness are central (Miller 2001). A key tenet of equity is social inclusion, although the subject is more usually understood by attempts to limit exclusion. As such, the study of the extent to which disabled tourists are able to enjoy an equal service to that enjoyed by nondisabled tourists can be seen as an essential part of sustainable tourism and sustainable development.

In 1995, the UK government introduced the Disability Discrimination Act, which made it illegal to;

- Refuse to serve a disabled person (S19)(1)(a) 
- Provide disabled people with a lower standard of service, or a service in a worse manner $(\mathrm{S} 19(1)(\mathrm{c})$

- Provide a disabled person with a service on worse terms (S19(1)(d)

Since then, the Act has been toughened, with the addition of the most recent part of the act in

October 1999. This requires organisations to;

- Change practices, policies or procedures which make it impossible or unreasonably difficult for disabled people to use a service.

- Provide auxiliary aids or services which could make it easier, or enable, disabled people to use a service.

- Overcome physical features which make it impossible or unreasonably difficult for disabled people to use a service, by providing the service by a reasonable method instead.

The extent to which "access for all" has been recognised as a central element of sustainability is demonstrated by its inclusion in the UK government's tourism policy, and so this research aimed to test how far tourism organisations were adhering with the new policy and regulation. It is a rare sign of the government's commitment to this aspect of the tourism policy that it commands the backing of legislation rather than the more usual frameworks and guidelines. This legislative stick has become even heavier throughout the course of the year 2000, with the introduction of the Disabilities Rights Commission. This commission, as with those for racial and sexual discrimination, has the powers to investigate and bring charges against nonconforming organisations. This research shows how far the threat of financial penalty for noncompliance could be waved.

\section{Background}

Campbell (2000) explains how the new DDA represents both a stick and a carrot for tourism companies. With upwards of 8 million disabled people in the UK and an ageing population, catering for the needs of this population represents a considerable enticement to amend current practices that exclude disabled people. 
The valuation of this market varies, but the English Tourist Council (English Tourist Board, at the time) estimates the market to be worth £6billion to the British Tourist Industry (Times 1996). Yet, $34 \%$ of disabled people did not take a holiday in 1998 and only $6 \%$ took a short break (ETC no date). This is despite research showing $76 \%$ of disabled people thought taking a holiday was important to them, a figure that rose to $84 \%$ of people aged between 16 and 44 years old (Inra 1999 cited in Royal National Institute for the Blind 2000a). In addition to this potential market, must be added the financial benefit accrued from carers and family members who are likely to travel with disabled people. Thus, for the organisation willing to make the necessary changes to current practices, there is a large financial benefit to behold as well as advancing the rights of disabled people in society.

However, Campbell (2000:A115) concluded his article by stating, "The current standards of provision for disabled people vary enormously from company to company...on the whole though, the present standards of service provision for disabled persons are far from satisfactory and there is much to be done to address this... They will have to start to take an active interest in the needs of disabled people and begin to work towards improvement".

The research conducted for this article tests how tourism companies in the UK have begun to work towards compliance with the DDA, and examines just how much work there is to do.

\section{The Research}

Of the 8 million disabled people in the UK, almost I million are blind or visually impaired, plus a further 700,000 who have some difficulties in seeing, and with an ageing population this figure is only set to increase (RNIB 2000b). Research by the RNIB shows $60 \%$ of those blind or with a visual impairment can be enabled if the written information meets simple requirements such as utilising large print, contrasting text and page colours and avoiding thin or glossy paper (see table one). 


\section{Insert Table One Here}

The RNIB argues, "Information is the key to independence. Independence is power. RNIB believes that blind and partially sighted people have a right to information in a format which is appropriate, without undue delay or additional charge" (RNIB 2000b). While Wickham \& Sullivan (1999:44) state, "The most important omission from the point of view of visually impaired visitors is the lack of access to printed information".

Indeed, in a world increasingly reliant on information, disabled people risk further social exclusion, not to mention frustration, by information not being available in a format that is appropriate to them. Further, if disabled people are not made aware of the services that a tourism organisation provides, then the full benefits of any efforts made at the destination itself are likely to be wasted. The DDA requires that auxiliary aids and services be provided to enable a disabled person to use a service, and the provision of information in a suitable format would be included within this category. As this would appear to be the most straightforward requirement made of organisations, and yet also a requirement that could affect a vast number of people, this was the area of compliance tested. It was anticipated that the level of compliance with the DDA would not be high, and thus a very simple request was made of all the organisations.

The annually produced Travel and Tourism Directory divides the industry into seven constituent parts. Broadly reflecting the number of entries for each section, twenty companies were randomly selected from the road, sea, air and rail companies, sixty from each of the attractions and hotels sections and ten from the tourist board entries. Thus, in total, two hundred and ten companies providing tourism services were selected and written to, utilising a mystery shopper approach, requesting basic information on prices, times and directions in order to be able to use the service of the organisation. The letter stated that the sender was visually impaired and would like the information to be sent in either a Braille or large print format, and specified the size font that would be readable. Although a mail merge facility was employed to generate the letters, each was individually tailored to the specifics of the 
recipient. The letter itself was sent in a large print format and in accordance with the RNIB's Clear Print Guidelines.

The research adapted the Dillman total design method (Dillman et al 1974) and ten days after sending the letters, reminders were sent to those organisations who had not replied, after another ten days a further round of reminders were sent, and then a final round of letters were mailed one month after the original request. While this approach is derived from social science to produce the maximum response rate, it was also felt that three letters would represent the number of times even the most patient of potential customers would persist with a company. A control group of requests made in standard print requesting the same information was not utilised, as it was assumed that all profit seeking organisations would respond if possible to an inquiring customer. Research by Wickham \& Sullivan (1999) of UK heritage sites showed that $97 \%$ of sites visited had information available in standard format, while only $31 \%$ could produce Braille guides, $27 \%$ audio guides and just $15 \%$ were available in large print. Thus, limited research funds were focused on testing the extent of organisations capabilities rather than their core competencies. Future research may care to examine this assumption.

\section{The Results}

Of the 210 letters sent to organisations, 32\% (68) did not reply in any way, and a further 10 letters were returned to sender. While a $68 \%$ response rate can be considered satisfactory, table two shows the uneven distribution of these non-replies. The low sample size prevents conclusive statistical evidence, but it would perhaps not be unreasonable to suggest that the variation in replies is at least in part due to the ability of organisations to reply, and thus comply with the DDA. Of note are the third of hotels who did not reply, $45 \%$ of sea travel organisations and $55 \%$ of road travel companies, as compared to less than $12 \%$ of attractions who did not reply.

\section{Insert Table Two Here}


Table three shows the responses of those who did reply. There was a large variety in the quality of responses, as identified by Campbell's (2000) comments at the beginning of the article. While no company was able to reply with Braille as the letter had requested, 35 companies did reply with a large print letter and a further 10 showed initiative and ran the standard letter through the photocopier machine until it was larger. Such simple steps are all that are required to comply with the DDA. The act requires only that "reasonable" steps be taken to accommodate disabled people, there is no intention to bankrupt tourism organisations, but it would be a poor definition of reasonable that was not able to include a little extra thought and consideration. Special mention must be given to the person at Brighton Pier who drew a wonderful map by hand on a large piece of paper and then included directions in large print in the letter. Such care and concern will prove invaluable in attracting and retaining disabled customers.

\section{Insert Table Three Here}

The largest category of respondents replied with a large print letter, but a standard brochure. In some cases the letter acknowledged that the brochure was not appropriate but hoped that it would be better than nothing. Often it wasn't, as the extensive use of colour in brochures means the main problem is one of contrast rendering text over the top of photographs and pictures illegible. This problem is all the more frustrating as the plain text version of a brochure is a necessary precursor to any colourful brochure produced. Thus, with some forward planning and consideration, the plain text version could be retained and then reproduced in large print, or any other format, as requested. Other letters expressed their intention to pass the failing onto their marketing and communications departments in order to address the deficiency. Such replies reflected the recency of the DDA and a willingness of organisations to respond, and as such should be applauded. Yet, while such organisations produced amongst the better responses, they have still been unable to provide a disabled tourist with the same level service afforded to an able bodied tourist. 
From evidence of some consideration, the next categories of response showed little thought or effort. Seven companies replied in standard print that they did not have a brochure in an appropriate format and so would have to refer the request, while 36 organisations ignored all requests made in the letter and replied with a standard letter and standard brochure.

Disappointingly, four of these organisations were tourist boards, many of whom run disability training schemes. This serves to demonstrate the need for training to permeate throughout an organisation and not just rest with a policy or the well intentioned few. Indeed, a future research option is to request a copy of the company's policy concerning the provision of information to disabled people independent of the mystery shopping research. Wickham \& Sullivan (1999) adopted this methodology by asking about the level of alternative information provision and then subsequently conducting a site visit. The result was broadly similar data. Such an approach was not adopted for this research because without funds for site visits there was an unknown risk of low response rates for the two separate requests not producing the two separate pieces of data for analysis. However, a satisfactory response rate for this research may indicate that, with funding, an approach checking policy against action is possible for the future.

The final groups of respondents included 11 organisations that sent hand-written replies, which were difficult for a fully sighted person to understand and the remaining 3 organisations sent what can only be described as truly "miscellaneous" replies that included one job application form.

By specifying in the letter to organisations the nature of the impairment and what format the reply should take, any organisations falling to meet those requests were in breach of the DDA 1999. Thus, taking a strict interpretation of what was asked for, only 45 organisations were able to comply, although a further 40 made some effort and promised future improvements. It will be insightful to repeat the research in a year to determine which of these organisations have responded to the challenge that they promised to investigate. However, for the majority of those surveyed, even the simplest of request has proved to be too challenging and in the process displayed an inability to attract nearly 2 million visually impaired and ageing potential 
customers. Had the research been repeated for a more stringent or challenging request, where the defence of cost could be waved, then it is reasonable to assume that the levels of compliance would have been even lower.

Across the industry categories there is a clear variety in quality of response and the attractions sector should be identified for praise. Of concern is the mixed response from the tourist boards, who have a clear responsibility to promote social inclusion, quite apart from their private sector commitments to their members. It will be interesting to test in future work, whether the public sector is any better at meeting the DDA requirements through a sense of social responsibility, than the private sector has been through the motivation of access to a wider market. Future areas of testing could also include those organisations that have been in receipt of government or lottery funding.

\section{Conclusions}

Meeting the requests made by this research should not have been difficult, it requires only thought and awareness of the problems faced by a disabled person. The overall picture is one of non-understanding, or misunderstanding as to how to deal with requests from disabled potential customers. Many of the companies surveyed can be described as excellent in the provision of service to the able bodied customer, but this research has demonstrated a gap in the quality of their total offering. In the past, tourism organisations not addressing disabled issues were guilty of missing a market opportunity and a lack of social equity. Now, if tourism organisations continue to fail to meet the often simple and reasonable needs of customers, who are trying to use tourism services, then it would not be unreasonable to believe that the threat of the stick, rather than the lure of the carrot will describe the future. Unfortunately, the DDA does not go away by attempting to bury the corporate head in the sand and refusing to come up until the awkward questions have gone away. 


\section{References}

Campbell, B (2000) Catering for Disabled People - The Carrot, the Stick and the Way

Forward. Insights, January, A-111 - A115

Dillman, D.A., Christensen, J.A., Carpenter, E.H., Brooks, R.M (1974) Increasing Mail

Questionnaire Responses: A Four State Comparison. American Sociological Review, 39, pp755

English Tourism Council (no date) Welcoming Disabled Travellers. ETC, London

Hunter, C (1995) On the Need to Re-conceptualise Sustainable Tourism Development.

Journal of Sustainable Tourism, 3 (3), pp155-165

Miller, G (2001) The Development of Indicators for Sustainable Tourism: Results of a Delphi Survey of Tourism Researchers. Tourism Management, 22, 4, pp351-362

Royal National Institute for the Blind (2000a) Welcoming Your Visually Impaired Customers: Tourism, RNIB, London

Royal National Institute for the Blind (2000b) Clear Print Guidelines.

http://www.rnib.org.uk/wesupply/fctsheet/clearp.htm, 23/03/2000

The Times (1996) New Disabled Law "will boost tourism". December $5^{\text {th }}$

Wickham, C., Sullivan, P (1999) Magical Mystery Tour: Access to Historic Sites and Buildings for Visually Impaired Visitors. University of Bristol Disability Unit. 


\begin{tabular}{|l|l|}
\hline Printed Text Should & Printed Text Should not \\
\hline Be a minimum of sized 14 font & Exceed sized 20 font \\
\hline Use a medium to heavy weighted font & Use glossy or thin paper \\
\hline Provide contrast with the colour of the page & Print text in capital letters \\
\hline Justify paragraphs to the left & \\
\hline Space words evenly & \\
\hline Use navigational aids such as headings & \\
\hline Use clear fonts e.g. sans serif & \\
\hline
\end{tabular}

Table One: Guidelines for Informational Products

Source: Adapted from RNIB (2000b)

\begin{tabular}{|c|c|c|c|c|}
\hline & No Reply & $\begin{array}{c}\text { Return to } \\
\text { Sender }\end{array}$ & Total \\
\hline \multirow{4}{*}{ Company Type } & Rail Travel & 3 & 1 & $4 / 20$ \\
\cline { 2 - 5 } & Sea Travel & 9 & 0 & $9 / 20$ \\
\cline { 2 - 5 } & Air Travel & 6 & 3 & $9 / 20$ \\
\cline { 2 - 5 } & Road Travel & 11 & 3 & $14 / 20$ \\
\cline { 2 - 5 } & Hotels & 20 & 2 & $22 / 60$ \\
\cline { 2 - 5 } & Attractions & 7 & 1 & $8 / 60$ \\
\cline { 2 - 5 } & Tourist Boards & 2 & 0 & $\mathbf{6 8 / 2 1 0}$ \\
\hline \multicolumn{2}{|c|}{ Total } & $\mathbf{5 6}$ & $\mathbf{1 0}$ & \\
\hline
\end{tabular}

Table Two: Non-respondents

\begin{tabular}{|c|c|c|c|c|c|c|c|c|c|c|}
\hline \multicolumn{11}{|c|}{ Quality of Responses } \\
\hline & & $\begin{array}{l}\text { Large } \\
\text { Print } \\
\text { Letter }\end{array}$ & $\begin{array}{l}\text { Photo- } \\
\text { copied } \\
\text { Letter }\end{array}$ & $\begin{array}{l}\text { Large } \\
\text { Print } \\
\text { Letter, } \\
\text { Std } \\
\text { Broch- } \\
\text { ure }\end{array}$ & $\begin{array}{l}\text { Large } \\
\text { Print } \\
\text { Letter, } \\
\text { Matter } \\
\text { For- } \\
\text { warded }\end{array}$ & $\begin{array}{l}\text { Std } \\
\text { Letter, } \\
\text { Matter } \\
\text { For- } \\
\text { warded }\end{array}$ & $\begin{array}{l}\text { Std } \\
\text { Letter } \\
\text { Std } \\
\text { broch } \\
\text {-ure }\end{array}$ & $\begin{array}{l}\text { Hand- } \\
\text { written } \\
\text { reply }\end{array}$ & Misc & Total \\
\hline \multirow{7}{*}{ 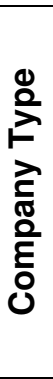 } & Rail Travel & & 3 & 1 & 4 & 4 & 3 & & 1 & $16 / 20$ \\
\hline & Sea Travel & 4 & & 1 & & 1 & 4 & 1 & & $11 / 20$ \\
\hline & Air Travel & 1 & 1 & 1 & & & 5 & 3 & & $11 / 20$ \\
\hline & $\begin{array}{l}\text { Road } \\
\text { Travel } \\
\end{array}$ & 2 & & & & & 2 & 2 & & $6 / 20$ \\
\hline & Hotels & 9 & 3 & 13 & & 1 & 10 & 1 & 1 & $38 / 60$ \\
\hline & Attractions & 15 & 3 & 19 & 1 & 1 & 8 & 4 & 1 & $56 / 60$ \\
\hline & $\begin{array}{l}\text { Tourist } \\
\text { Boards }\end{array}$ & 4 & & & & & 4 & & & $8 / 10$ \\
\hline & Total & 35 & 10 & 35 & 5 & 7 & 36 & 11 & 3 & $142 / 210$ \\
\hline
\end{tabular}

Table Three: Quality of Respondents 